\title{
Differences between Saline and Mannitol Diuresis in Hydropenic Man*
}

\author{
Martin Goldberg, $†$ Donna K. McCurdy, and Manuel A. Ramirez \\ (From the Chemical Section of the Department of Medicine, University of Pennsylvania \\ School of Medicine, Philadelphia, Pa.)
}

In the hydropenic intact animal, knowledge of solute and water transfers in the renal concentrating operation may be obtained by utilizing osmotic diuresis (2-5). Changes in the urine to plasma osmotic ratio $\left(\mathrm{U}_{\mathrm{osm}} / \mathrm{P}_{\text {osm }}\right)$ and tubular reabsorption of solute-free water $\left(\mathrm{T}^{\mathrm{c}} \mathrm{H}_{2} \mathrm{O}\right)$ with increasing rates of total. solute clearance $\left(\mathrm{C}_{\text {osm }}\right)$ and urine flow (V) may give information pertaining to the limits of the mechanisms involved in the concentration of urine. Much of the data obtained from normal man with this technique has been derived from studies employing hypertonic mannitol as the loading solute $(3,5)$. These studies have characteristically shown that, during mannitol diuresis in hydropenia, $\mathrm{T}^{\mathbf{c}} \mathbf{H}_{2} \mathrm{O}$ achieves an upper limit or maximum when $\mathrm{C}_{\text {osm }}$ exceeds $15 \mathrm{ml}$ per minute and that urine osmolality approaches the osmolality of plasma as a limit. If $\mathrm{T}^{\mathrm{c}} \mathrm{H}_{2} \mathrm{O}$ is an index of water movement from the collecting duct into the hypertonic medullary interstitium, then it is probably a reflection of the rate of transport and accumulation of solute (chiefly sodium chloride) in the renal medulla. The observed upper limit to $\mathrm{T}_{\mathrm{H}_{2} \mathrm{O}}$ with mannitol diuresis might indicate an intrinsic maximal capacity for the active transport of sodium in the ascending limb of the loop of Henle $(5,6)$. This interpretation, however, is at variance with the observations made in micropuncture studies in rats during saline loading that fail to show any

\footnotetext{
* Submitted for publication August 25, 1964 ; accepted October 14, 1964.

Supported by U. S. Public Health Service grants $\mathrm{HE}$ 07284-02, HE 00340-16, 3MO1 FR40-04, and the C. Mahlon Kline Fund for the development of the Department of Medicine.

A preliminary report of this work was presented at the National Meeting of the American Federation for Clinical Research, Atlantic City, May 3, 1964 (1).

† Supported by a Research Career Development Award, U. S. Public Health Service grant 5K3 AM 18582-03.
}

evidence of saturation or a tubular maximum for sodium transport in the loop of Henle (7-9).

If the conclusions drawn from mannitol experiments in man are generally true of osmotic diuresis, then any loading solute that increases the rate of delivery of sodium into the loop of Henle without directly altering the tubular transport systems should produce qualitatively similar effects on $\mathrm{T}^{\mathrm{c}}{ }_{\mathrm{H}_{2} \mathrm{O}}$ and $\mathrm{U}_{\text {osm }} / \mathrm{P}_{\text {osm }}$. On the other hand, it is possible that mannitol diuresis, by lowering the intratubular sodium concentration (10), may impose an inhibitory influence on medullary sodium transport, thus producing a "pseudomaximum" to $\mathrm{T}^{\mathbf{c}} \mathrm{H}_{2} \mathrm{O}$.

In the present study, the effects of hypertonic saline diuresis in hydropenic man were observed and compared to mannitol diuresis. The administration of hypertonic sodium chloride not only increases the load of sodium entering the loop of Henle, but also increases the sodium concentration of late proximal tubular fluid (8). The results indicate that during saline diuresis, no evidence of a maximal upper limit to $\mathrm{T}^{\mathbf{c}} \mathrm{H}_{2} \mathrm{O}$ is present, in contrast to mannitol diuresis. Medullary solute accumulation appears to be enhanced by raising tubular sodium concentration. The limitation imposed by mannitol on medullary solute accumulation is, at least in part, secondary to its ability to markedly lower sodium concentration at the end of the proximal convoluted tubule.

\section{Methods}

Experimental procedure. Seventeen acute studies were performed on eight healthy male human volunteers in the Clinical Research Center of the Hospital of the University of Pennsylvania. All subjects were between the ages of 23 and 30 except WB, who was 42 years old. Before each experiment, fluids were omitted for 15 to 17 hours, and the study was begun at 8:30 to 9:00 a.m. All subjects assumed the recumbent position except when standing to void. 
A priming dose of inulin was given, and an infusion of isotonic saline containing inulin and vasopressin was administered at a rate of $1 \mathrm{ml}$ per minute with a Holter constant infusion pump. The quantities of these substances in the material infused provided a sustaining infusion of inulin for clearance determinations and the administration of $350 \mathrm{mU}$ per hour of vasopressin. Blood specimens were obtained every 30 to 60 minutes at the mid-point of a urine collection period.

After an initial urine collection period of 45 to $90 \mathrm{~min}$ utes, an infusion of loading solute was begun. In seven experiments, $10 \%$ mannitol in $100 \mathrm{mM}$ sodium chloride was started at a rate of 10 to $12 \mathrm{ml}$ per minute, and the infusion rate was increased periodically as necessary until solute clearance was between 20 and $40 \mathrm{ml}$ per minute, according to the tolerance of each subject. In seven studies, $3 \%$ sodium chloride was given at an initial rate of 10 to $12 \mathrm{ml}$ per minute, and the infusion was continued until solute clearance achieved values between 20 and $35 \mathrm{ml}$ per minute.

Four of the above subjects received hypertonic mannitol and hypertonic saline on two different days (LB, JC,
$\mathrm{RK}, \mathrm{FB}$ ), and in $\mathrm{RK}$ and FB, two different mannitol experiments were performed. Three additional studies were done on $\mathrm{LB}, \mathrm{JC}$, and $\mathrm{RK}$, in which the initial loading solute was hypertonic mannitol, and when solute clearance exceeded $15 \mathrm{ml}$ per minute, $3 \%$ sodium chloride was substituted for the mannitol at a rate of 12 to 15 $\mathrm{ml}$ per minute. This infusion was continued until solute clearance reached values between 25 and $35 \mathrm{ml}$ per minute. These latter experiments were done to allow comparison between the two loading solutes in the same subject on the same day.

Chemical methods and calculations. All of the urine and blood specimens were analyzed for sodium, potassium, chloride, creatinine, osmolality, and inulin by the methods previously described (11). Urea was determined in blood and urine by the Conway microdiffusion method (12). $\mathrm{C}_{\mathrm{os} m}$ and $\mathrm{T}^{\mathrm{c}} \mathrm{H}_{2} \mathrm{O}$ were calculated by the following formulas : $\mathrm{C}_{\text {osm }}=\left(\mathrm{U}_{\mathrm{osm}} \times \mathrm{V}\right) / \mathrm{P}_{\mathrm{osm}}$, and $\mathrm{T}_{\mathrm{H}_{2} \mathrm{O}}^{\mathrm{c}}=\mathrm{C}_{\mathrm{osm}}-$ $\mathrm{V}$, where $\mathrm{U}_{\mathrm{osm}}=$ osmolality of urine (milliosmoles per kilogram), $\mathrm{P}_{\text {osm }}=$ osmolality of serum (milliosmoles per kilogram), and $V=$ urine flow (milliliters per minute). Nonurea solute concentration of urine was estimated
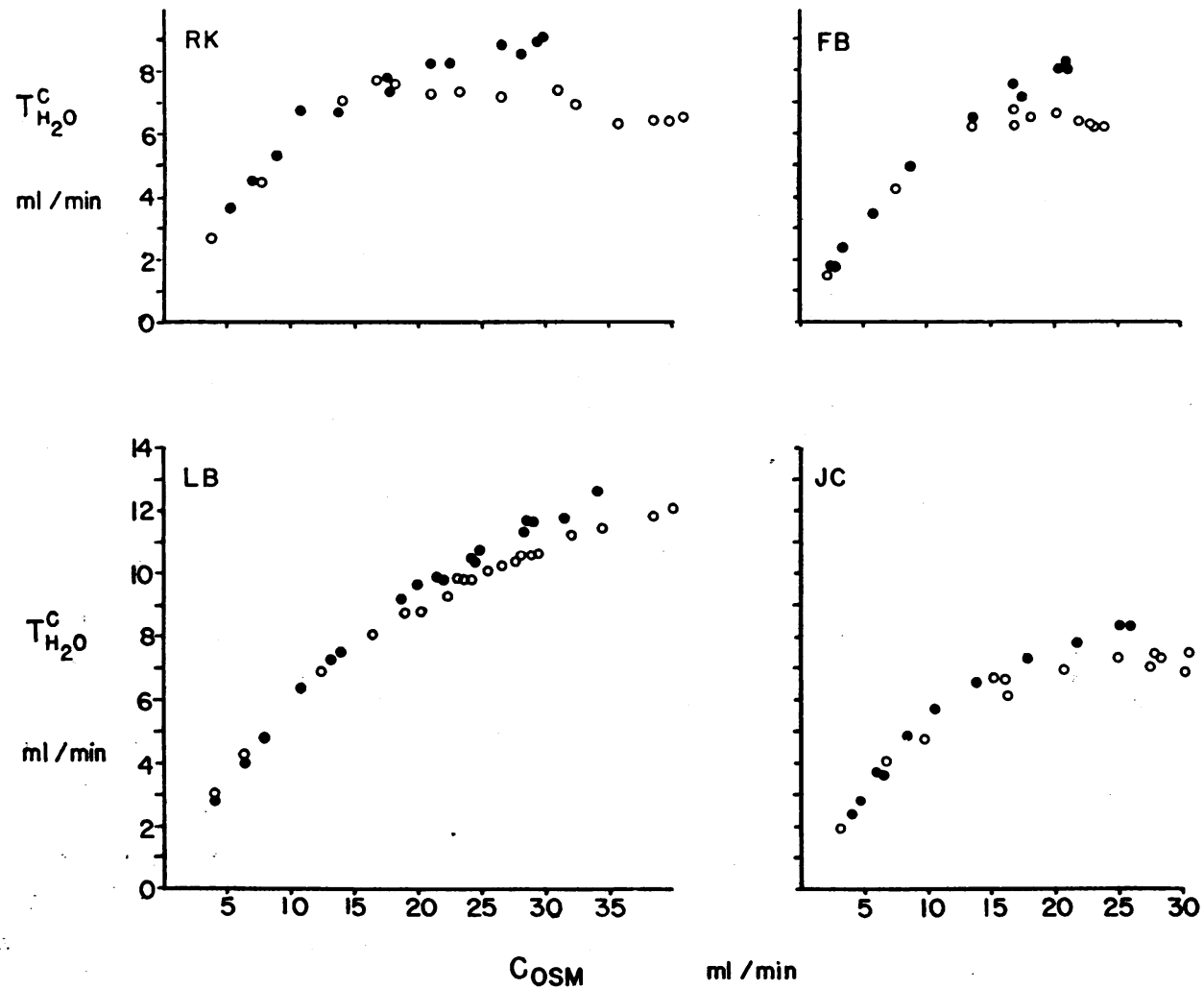

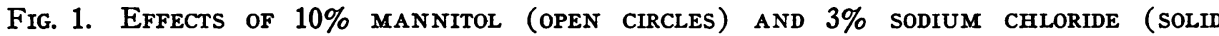
CIRCLES) ON TUBULAR REABSORPTION OF SOLUTE-FREE WATER, $\mathrm{T}^{\mathbf{c}} \mathrm{H}_{2} \mathrm{O}$. Data represent paired studies in four subjects. Note divergence of the two curves when osmolal clearance ( $\mathrm{C}_{\text {osm }}$ ) exceeds $15 \mathrm{ml}$ per minute. $\mathrm{T}^{\mathrm{C}}{ }_{\mathrm{H}_{2} \mathrm{O}}$ continues to rise at a decreasing rate in all saline studies in contrast to mannitol. Subject LB is the only one in whom the mannitol curve did not level off. 
TABLE I

Mannitol and saline diuresis during hydropenia: protocols of three different experiments in the same subject $(R K)^{*}$

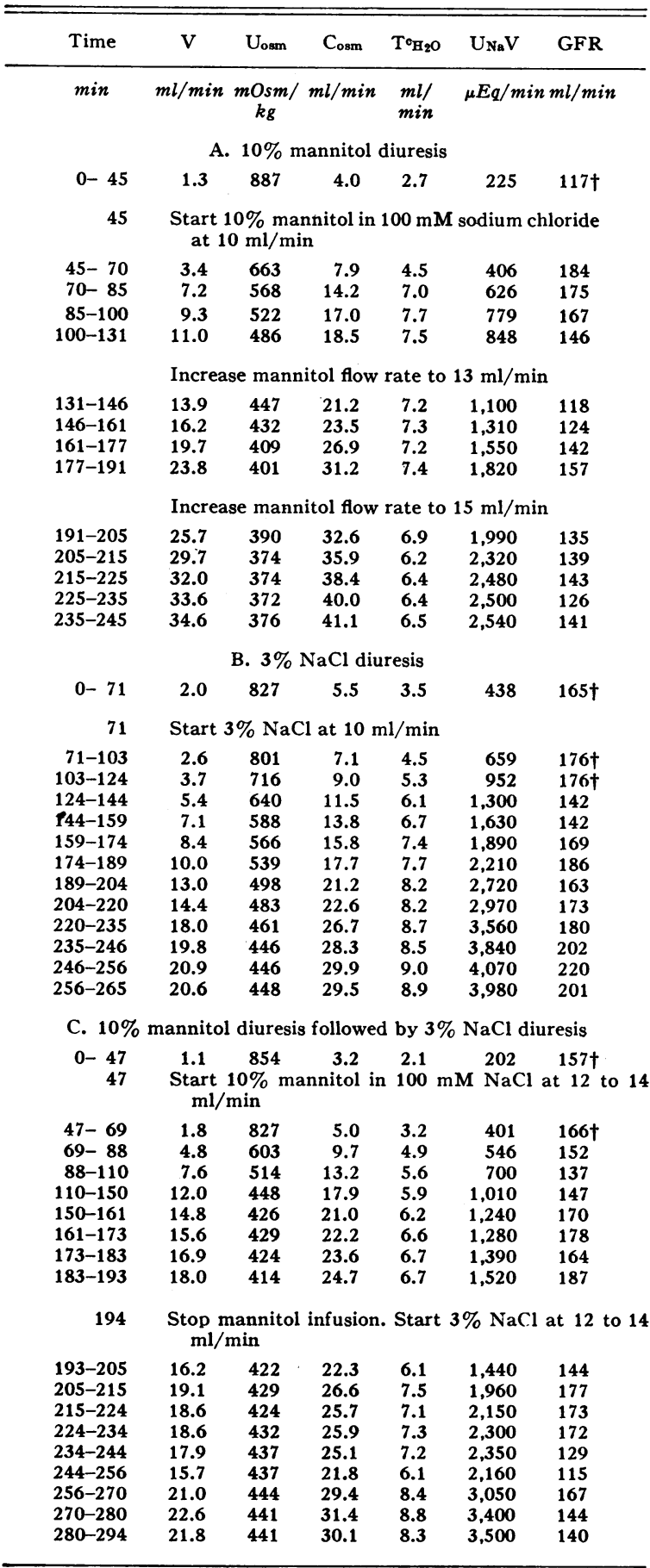

* Abbreviations: $\mathrm{V}=$ urine flow, $\mathrm{U}_{\mathrm{osm}}=$ urine osmolality, Cosm $=$ osmolal clearance, $\mathrm{T}^{\circ} \mathrm{H}_{2} \mathrm{O}=$ tubular reabsorption of solute-free water. $\mathrm{U}_{\mathrm{NaV}}=$ sodium excretion, and $\mathrm{GRF}=$ glomerular filtration rate. Values a re not corrected to $1.73 \mathrm{~m}^{2} \mathrm{BSA}$.

+ Clearance of endogenous creatinine. All other values for GFR represent clearance of inulin. by subtracting the urea concentration of urine (millimoles per liter) from $U_{\text {osm. }}$. Statistical calculations were performed by standard techniques (13).

\section{Results}

Effects on $T^{c} \mathrm{H}_{2} \mathrm{O}$. The relationship between $\mathrm{T}^{\mathrm{c}} \mathrm{H}_{2} \mathrm{O}$ and $\mathrm{C}_{\mathrm{osm}}$ in four subjects $(\mathrm{RK}, \mathrm{FB}, \mathrm{LB}$, JC) in whom paired studies with $10 \%$ mannitol and $3 \%$ sodium chloride diuresis were performed on separate days is shown in Figure 1. Protocols of representative mannitol, sodium chloride, and combined experiments in subject $\mathrm{RK}$ are given in Table I. Table II presents a summary of all single experiments with mannitol or salt. To allow a comparison between the two groups at high rates of solute excretion, the data in Table II are taken from periods during the solute diuresis when $\mathrm{C}_{\text {osm }}$ was approximately $18 \mathrm{ml}$ per minute per $1.73 \mathrm{~m}^{2} \mathrm{BSA}$.

With the exception of subject LB, characteristic curves of $\mathrm{T}^{\mathrm{c}_{2} \mathrm{O}}$ vs. $\mathrm{C}_{\mathrm{osm}}$ during mannitol diuresis were obtained in all studies. As $\mathrm{C}_{\text {osm }}$ increased to $12 \mathrm{ml}$ per minute per $1.73 \mathrm{~m}^{2}, \mathrm{~T}^{\mathrm{c}} \mathrm{H}_{2} \mathrm{O}$ rose progressively to values of 5.6 to $7.1 \mathrm{ml}$ per minute per $1.73 \mathrm{~m}^{2}$. As $\mathrm{C}_{\mathrm{osm}}$ increased further, $\mathrm{T}^{\mathrm{c}} \mathrm{H}_{2} \mathrm{O}$ levelled off, and at very high values of $\mathrm{C}_{\mathrm{osm}}, \mathrm{T}^{\mathrm{c}} \mathrm{H}_{2} \mathrm{O}$ fell slightly. In subject $\mathrm{LB}$, in contrast to all the others, $\mathrm{T}^{\mathbf{c}} \mathrm{H}_{2} \mathrm{O}$ never levelled off, even at a $\mathrm{C}_{\text {osm }}$ of $31.3 \mathrm{ml}$ per minute per $1.73 \mathrm{~m}^{2}$. In three other mannitol studies not illustrated in Figure $1\left(\mathrm{RK}_{2}\right.$, $\mathrm{FB}_{2}$, and $\mathrm{WB}$ ), an upper limit or maximum to $\mathrm{T}^{\mathbf{c}} \mathbf{H}_{2} \mathrm{O}$ was also manifest.

The data from the experiments with $3 \%$ sodium chloride were different from the mannitol studies both quantitatively and qualitatively with regard to $\mathrm{T}^{\mathrm{c}}{ }_{\mathrm{H}_{2} \mathrm{O}}$ formation. In these studies, the initial portion of the curve $\mathrm{T}_{\mathrm{H}_{2} \mathrm{O}}$ vs. $\mathrm{C}_{\mathrm{osm}}$ rose in a manner similar to the mannitol diuresis. When $\mathrm{C}_{\text {osm }}$ exceeded 10 to $15 \mathrm{ml}$ per minute, however, there was a distinct divergence of the salt and mannitol curves. At high rates of solute clearance, $\mathrm{T}^{\mathrm{c}}{ }_{\mathrm{H}_{2} \mathrm{O}}$ was higher with the salt infusion as compared to mannitol when paired studies were performed in the same subjects (Figure 1). As seen in Table II, at a mean $\mathrm{C}_{\text {osm }}$ of $17.9 \mathrm{ml}$ per minute per $1.73 \mathrm{~m}^{2}$, the mean value for $\mathrm{T}^{\mathrm{c}} \mathrm{H}_{2} \mathrm{O}$ for all sodium chloride studies was $7.5 \pm 0.9 \mathrm{ml}$ per minute per $1.73 \mathrm{~m}^{2}$ compared to $6.1 \pm 0.7 \mathrm{ml}$ per minute per $1.73 \mathrm{~m}^{2}$ in the mannitol group. These 
TABLE II

Summary of individual studies with hypertonic mannitol and saline*

\begin{tabular}{|c|c|c|c|c|c|c|c|c|c|c|c|}
\hline \multicolumn{10}{|c|}{ Data at comparable values of osmolal clearance } & \multirow{2}{*}{\multicolumn{2}{|c|}{$\begin{array}{c}\text { Highest values } \\
\text { in study }\end{array}$}} \\
\hline \multirow[b]{2}{*}{ Subject } & \multirow[b]{2}{*}{ Cosm $t$} & \multirow[b]{2}{*}{ Vt } & \multirow{2}{*}{$\frac{U_{\text {osm }}}{P_{\text {osm }}}$} & \multirow{2}{*}{$\frac{U_{\text {NuS }}}{P_{\text {osm }}}$} & \multirow{2}{*}{$\frac{\text { UUren }}{\text { Posm }}$} & \multirow[b]{2}{*}{$\mathrm{T}^{\circ} \mathrm{H}_{2} \mathrm{O} t$} & \multirow[b]{2}{*}{$\mathrm{UNaV}_{\mathbf{N}}$} & \multirow[b]{2}{*}{ GFR† } & \multirow{2}{*}{$\begin{array}{l}\text { Slope of } \\
\text { line (b) } \ddagger \\
\text { Cosm vs. V }\end{array}$} & & \\
\hline & & & & & & & & & & Cosmt & $\mathrm{T}^{\mathbf{e}_{\mathrm{H}} \mathrm{O}}$ \\
\hline & $m l / m i n$ & $m l / \min$ & & & & $m l / m i n$ & $\mu E q / \min$ & $\operatorname{ml} / \min$ & & $m l / m i n$ & $m l / m i n$ \\
\hline \multicolumn{12}{|c|}{$10 \%$ mannitol } \\
\hline WB & 17.4 & 12.1 & 1.44 & 1.37 & 0.07 & 5.3 & 845 & 97 & 1.04 & 26.7 & 6.1 \\
\hline LB & 17.6 & 10.2 & 1.72 & 1.60 & 0.12 & 7.4 & 1,050 & 87 & 1.11 & 31.3 & 9.4 \\
\hline JC & 17.4 & 12.3 & 1.49 & 1.42 & 0.07 & 6.1 & 878 & 95 & 1.03 & 27.1 & 6.6 \\
\hline $\mathbf{R} \mathbf{K}_{\mathbf{1}}$ & 17.8 & 12.3 & 1.45 & 1.34 & 0.11 & 5.5 & 994 & 94 & 0.91 & 31.2 & 5.6 \\
\hline $\mathbf{R K}_{\mathbf{2}}$ & 18.3 & 12.5 & 1.47 & 1.41 & 0.06 & 5.8 & 1,070 & 119 & 1.00 & 18.9 & 5.8 \\
\hline $\mathbf{F B}_{1}$ & 18.3 & 11.7 & 1.57 & 1.53 & 0.04 & 6.6 & 630 & . 110 & 1.02 & 21.0 & 7.1 \\
\hline$F_{B_{2}}$ & 17.7 & 12.0 & 1.48 & 1.42 & 0.06 & 5.7 & 681 & 111 & 1.06 & 21.1 & 5.9 \\
\hline Mean & 17.9 & 11.9 & 1.52 & 1.45 & 0.07 & 6.1 & 878 & 102 & 1.02 & & \\
\hline SD & 0.7 & 0.8 & 0.10 & 0.09 & 0.02 & 0.7 & 276 & 12 & 0.06 & & \\
\hline \multicolumn{12}{|c|}{$3 \%$ sodium chloride } \\
\hline LB & 17.4 & 9.6 & 1.81 & 1.65 & 0.16 & 7.8 & 2,310 & 157 & 1.28 & 27.2 & 10.0 \\
\hline JC & 17.5 & 10.9 & 1.62 & 1.52 & 0.10 & 6.6 & 2,370 & 115 & 1.20 & 22.8 & 7.3 \\
\hline $\mathbf{R K}$ & 18.4 & 12.1 & 1.53 & 1.41 & 0.12 & 6.3 & 2,440 & 132 & 1.14 & 22.3 & 6.7 \\
\hline FB & 17.9 & 10.9 & 1.64 & 1.55 & 0.09 & 7.0 & 2,460 & 117 & 1.25 & 18.3 & 7.2 \\
\hline PL & 17.5 & 9.5 & 1.88 & 1.70 & 0.18 & 8.0 & 2,260 & 166 & 1.47 & 26.1 & 10.8 \\
\hline $\mathrm{CS}$ & 18.6 & 10.4 & 1.81 & 1.75 & 0.06 & 8.2 & 2,500 & 120 & 1.16 & 27.3 & 9.6 \\
\hline MA & 17.9 & 10.3 & 1.74 & 1.58 & 0.16 & 7.6 & 2,400 & 135 & 1.36 & 19.8 & 8.3 \\
\hline Mean & 17.9 & 10.4 & 1.74 & 1.59 & 0.15 & 7.5 & 2,390 & 135 & 1.27 & & \\
\hline SD & 0.5 & 0.9 & 0.13 & 0.12 & 0.04 & 0.9 & 85 & 20 & 0.12 & & \\
\hline $\mathrm{p} \S$ & & $<0.02$ & $<0.02$ & $<0.05$ & $<0.01$ & $<0.001$ & & $<0.01$ & $<0.005$ & & \\
\hline
\end{tabular}

* Abbreviations as in Table I. Posm = plasma osmolality; UNUS = urinary concentration of nonurea solute; UUroa = urinary concentration of urea; $b=$ slope of regression line.

b = slope of regression line.

- IThese slopes (b) are taken from the plot of $C_{0 m}$ vs. V, when the relationship is linear. They are calculated from the equation, Uosm/ $\mathrm{P}_{\text {osm }}$ $=(a / V)+b$, which is derived from the plot of Cosm vs. $V$, when th

\$The values for $p$ pertain to the mean values of the mannitol and the sodium chloride groups for each variable.

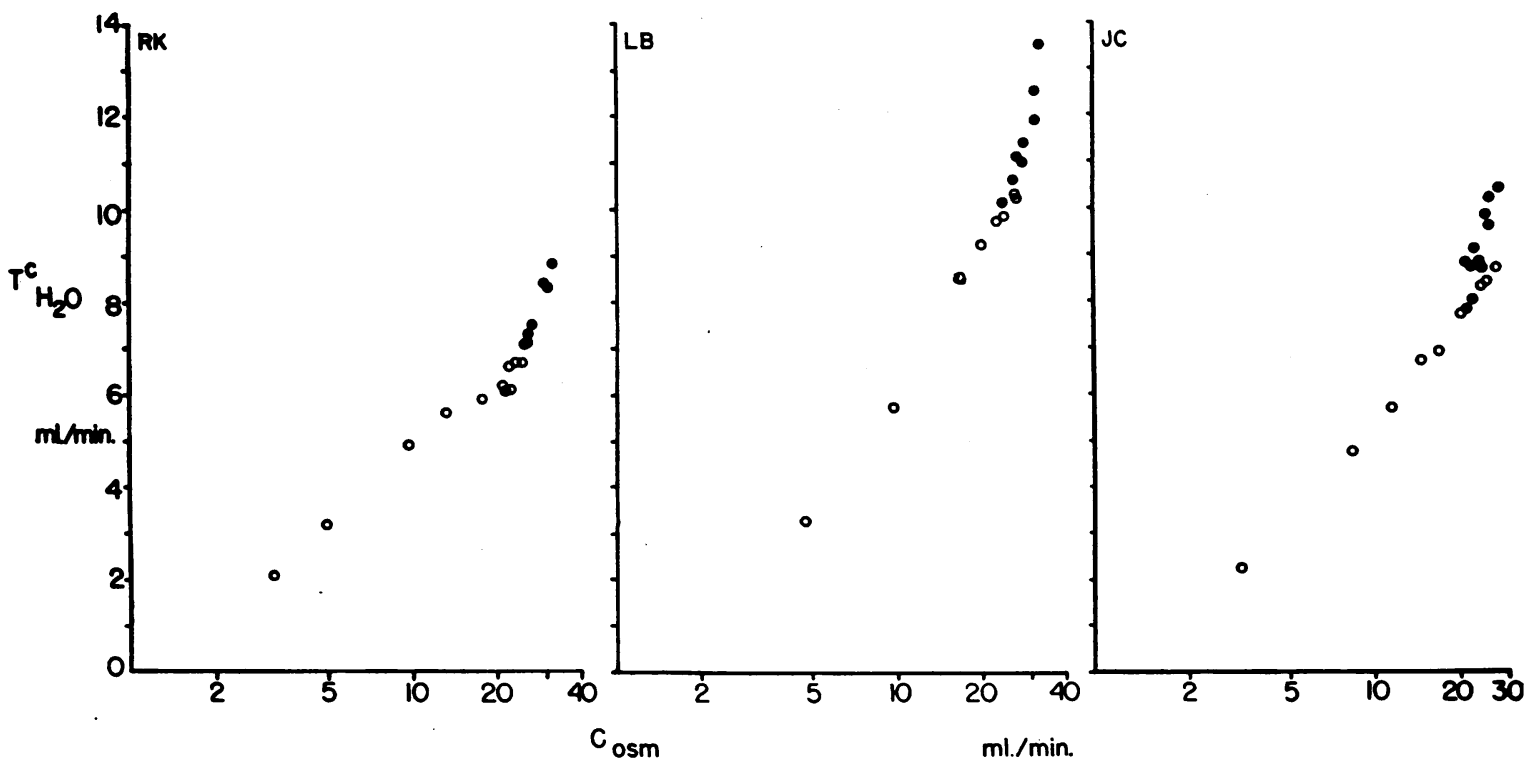

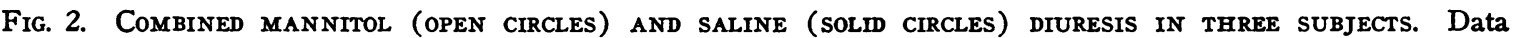
are plotted semilogarithmically ( $\mathrm{T}^{e}{ }_{\mathrm{H} 2 \mathrm{O}}$ vs. $\log \mathrm{C}_{\mathrm{osm}}$ ). Note the sharp rise in the slope of the curve following the superimposition of hypertonic saline diuresis on an established mannitol diuresis. See text. 
are significantly different from each other $(\mathrm{p}<$ $0.001)$.

Probably, a more important difference between salt and mannitol studies is in the configuration of the curves of $\mathrm{T}^{\mathbf{c}}{ }_{\mathbf{H}_{2} \mathrm{O}}$ vs. $\mathrm{C}_{\mathrm{osm}}$. In contrast to mannitol, the salt curve was characterized by a progressive rise at a decelerating rate so that in none of the studies was there evidence of an upper limit or maximum, even when $\mathrm{C}_{\text {osm }}$ exceeded $27 \mathrm{ml}$ per minute per $1.73 \mathrm{~m}^{2}$. At the highest rates of $\mathrm{C}_{\text {osm }}$ obtained in the study, values for $\mathrm{T}^{\mathrm{c}}{ }_{\mathrm{H}_{2} \mathrm{O}}$ exceeding $9.5 \mathrm{ml}$ per minute per $1.73 \mathrm{~m}^{2}$ were achieved (subjects $\mathrm{LB}, \mathrm{PL}, \mathrm{CS})$. When $\mathrm{T}^{\mathrm{c}}{ }_{\mathrm{H}_{2} \mathrm{O}}$ was plotted vs. $\log \mathrm{C}_{\text {osm }}$ or $\log \mathrm{U}_{\mathrm{Na}} \mathrm{V}$, a linear relationship was obtained in all of the saline experiments in contrast to the mannitol studies, in which the curves levelled off.

To make certain that these differences between hypertonic mannitol and sodium chloride diuresis were not due to the fact that these studies were performed on different days, the combined ex- periments were performed. In three subjects (RK, LB, and JC), the study was begun with an infusion of $10 \%$ mannitol, and when $\mathrm{C}_{\text {osm }}$ exceeded $15 \mathrm{ml}$ per minute $3 \%$ sodium chloride was substituted for the mannitol (Table IC and Figure 2). Note the abrupt rise in $\mathrm{T}^{\mathrm{c}} \mathrm{H}_{2} \mathrm{O}$ and the increase in the slope of the curve following the institution of the saline infusion, markedly altering the relationship between $\mathrm{T}^{\mathrm{c}} \mathrm{H}_{2} \mathrm{O}$ and $\mathrm{C}_{\mathrm{osm}}$, which was present during the preceding mannitol diuresis. $\mathrm{T}_{\mathrm{H}_{2} \mathrm{O}}$ was still rising at a $\mathrm{C}_{\mathrm{osm}}$ exceeding $30 \mathrm{ml}$ per minute, corresponding to a total solute excretion greater than $9,000 \mu \mathrm{Osm}$ per minute.

Although mean values for $\mathrm{T}^{\mathrm{c}}{ }_{\mathbf{H}} \mathrm{O}$ for both groups at a given rate of $\mathrm{C}_{\text {osm }}$ differed significantly, there were variations in the actual levels of $\mathrm{T}^{\mathbf{c}} \mathrm{H}_{2} \mathrm{O}$ achieved in the individual experiments (See Table II). However, the consistent differences between the saline experiments and mannitol experiments were in the configuration of the curve and the rate of change in $\mathrm{T}^{\mathrm{c}} \mathrm{H}_{2} \mathrm{O}$. This can be

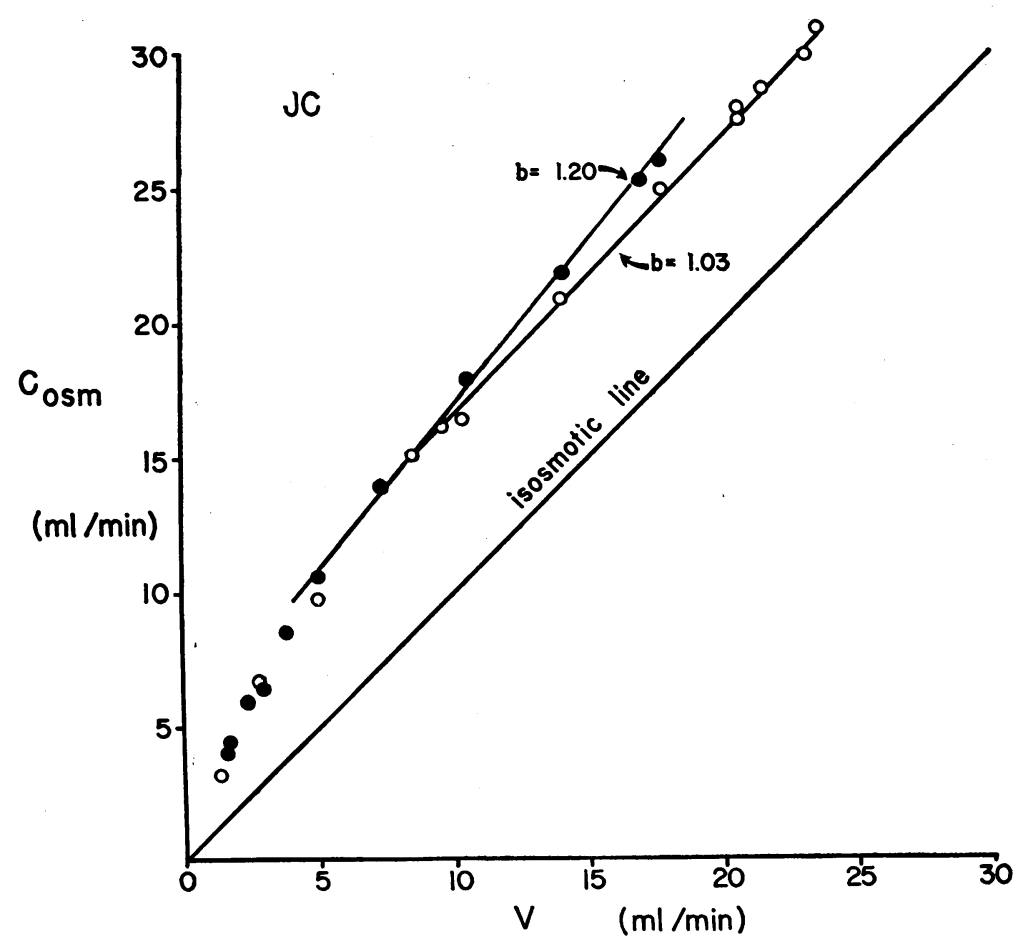

Fig. 3. Relationship between osmolal clearance (Cosm) and URINe FLOW (V) IN HYPERTONIC SALINE (SOLID CIRCLES) AND HYPERTONIC MANNITOL (OPEN CIRCLES) DIURESIS PERFORMED ON SUBJECT JC ON TWO DIFFERENT DAYs. The slope (b) of the regression line with saline is 1.20 , indicating a progressively increasing $\mathrm{T}^{\mathrm{c}} \mathrm{H}_{2} \mathrm{O}$ in contrast to the slope of 1.03 with mannitol, indicating a relatively constant $T^{c}{ }_{H_{2} O}$. See text. 
better illustrated by plotting $\mathrm{C}_{\text {osm }}$ vs. $\mathrm{V}$, as shown in Figure 3. In this type of curve, since the isosmotic line has a slope of one, any experimental line with a similar slope indicates a relatively constant $\mathrm{T}_{\mathrm{H}_{2} \mathbf{O}}$, and a line with a slope greater than one signifies a progressively increasing $\mathrm{T}^{\mathrm{c}} \mathrm{H}_{2} \mathrm{O}$. In Figure 4 are shown the data from a hypertonic mannitol and hypertonic saline study in subject JC. The slope of the mannitol line is 1.03 and of the saline line, 1.20. The calculated slopes of the regression line of $\mathrm{C}_{\text {osm }}$ vs. $\mathrm{V}$, in all individual experiments, are given in Table II. In every mannitol experiment, the slope was less than 1.12 with a mean value of $1.02 \pm 0.06$. In contrast, the slope in the saline experiments varied from 1.14 to 1.47 with a mean value of $1.27 \pm 0.12$. The means of the two groups are significantly different from each other $(p<0.005)$.

If, at high rates of $\mathrm{C}_{\mathrm{osm}}, \mathrm{T}^{\mathrm{c}} \mathrm{H}_{2} \mathrm{O}$ is higher with saline than with mannitol diuresis, it follows that the $\mathrm{U}_{\mathrm{osm}} / \mathrm{P}_{\mathrm{osm}}$ at a given $\mathrm{C}_{\mathrm{osm}}$ is also higher during saline diuresis (Figure 4) and that the asymptotic limit of the saline curve of $\mathrm{U}_{\text {osm }} / \mathrm{P}_{\text {osm }}$ vs. $\mathrm{C}_{\text {osm }}$ is higher than the mannitol curve. In the lower portion of Figure 4, $U_{\text {osm }}$ is broken down into its components of urea ( $U_{\text {Urea }}$ ) and nonurea solute ( $U_{\mathrm{NUS}}$ ) concentrations. An interesting observation noted in all saline experiments was the maintenance of control levels of $U_{\text {NUs }}$ up to a $\mathrm{C}_{\text {osm }}$ of 10 to $12 \mathrm{ml}$ per minute in contrast to mannitol diuresis. With saline, the sole reason for the early sharp fall in $\mathrm{U}_{\text {osm }} / \mathrm{P}_{\text {osm }}$ was the decrease in $U_{\text {Urea }} / \mathrm{P}_{\text {osm. }}$. With mannitol, the early phase of the diuresis was associated with a fall in both $\mathrm{U}_{\text {Urea }} / \mathrm{P}_{\text {osm }}$ and $\mathrm{U}_{\mathrm{NUS}} / \mathrm{P}_{\text {osm. }}$. At high values of $\mathrm{C}_{\text {osm }}$ in both types of diuresis, urea contributed negligibly to $U_{\text {osm }}$ and, therefore, to the calculation of $\mathrm{T}^{\mathrm{c}} \mathrm{H}_{2} \mathrm{O}$.

Effects on urinary sodium excretion $\left(U_{N a} V\right)$, plasma sodium concentration $\left(P_{N a}\right)$, and glomerular filtration rate $(G F R)$. Progressive increases in $\mathrm{U}_{\mathrm{Na}} \mathrm{V}$ occurred during both types of solute diuresis, and, as expected, $\mathrm{U}_{\mathrm{Na}} \mathrm{V}$ and $\mathrm{U}_{\mathrm{Na}} / \mathrm{C}_{\text {osm }}$ were greater at any $\mathrm{C}_{\text {osm }}$ with saline diuresis than with mannitol (Table II). In both saline and mannitol diuresis, there were also progressive increases in the fraction of filtered sodium that was excreted $\left(\mathrm{C}_{\mathrm{Na}} / \mathrm{GFR}\right)$, approaching values of 15 to $18 \%$ at the highest rates of solute excretion.

$\mathrm{P}_{\mathrm{Na}}$ increased with hypertonic saline loading

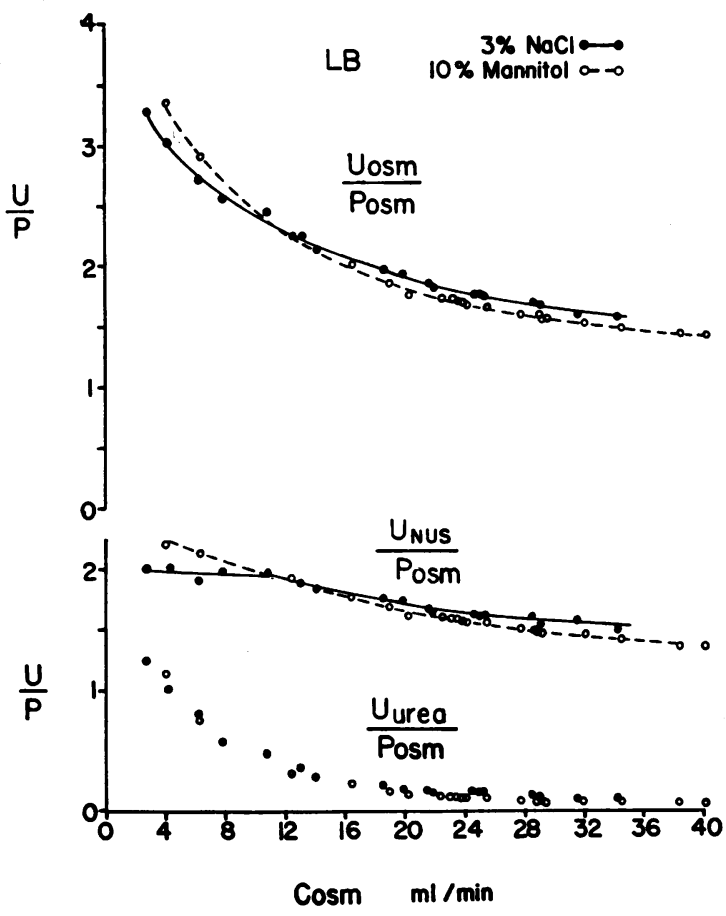

Fig. 4. EFFECTS ON URINE to PLASMa OSMOTIC RATIO (U $\mathrm{U}_{\text {osm }} / \mathrm{P}_{\text {osm }}$ ) AND ITS COMPONENTS, NONUREA SOLUTE CONCENTRATION PER UNIT PLASMa OSMOLALITY (U UVS/Posm) AND UREA CONCENTRATION PER UNIT PLASMA OSMOLALITY (U $U_{\text {Jrea }} / P_{\text {osm }}$ ), IN SUBJECT LB. In both types of diuresis, $U_{\text {Urea }} / P_{\text {osm }}$ falls sharply in the initial phase so that above a $\mathrm{C}_{\text {osm }}$ of $12 \mathrm{ml}$ per minute, $\mathrm{U}_{\mathrm{NUS}} / \mathrm{P}_{\text {osm }}$ determines the $U_{\text {osm }} / \mathrm{P}_{\text {osm }}$ curve. At low rates of $\mathrm{C}_{\mathrm{osm}}, \mathrm{U}_{\mathrm{NUg}} / \mathrm{P}_{\text {osm }}$ remained stable with saline diuresis in contrast to mannitol diuresis.

and decreased with mannitol loading. In each saline experiment, the correlation coefficient between $\mathrm{T}^{\mathrm{c}} \mathrm{H}_{2 \mathrm{O}}$ and $\mathrm{P}_{\mathrm{Na}}$ was greater than 0.94 ( $\mathrm{p}<$ $0.01),{ }^{1}$ (Table III). This relationship is illustrated in the data from subject LB shown in Figure 5. Also, in each saline study a significant correlation was present between $\log \mathrm{U}_{\mathrm{Na}} \mathrm{V}$ and $\mathrm{P}_{\mathrm{Na}}$, similar to the observations of Blythe and Welt (14) in dogs. The values for $r$ varied from 0.606 to 0.988 and were statistically significant (Table III). Since $\mathrm{T}^{\mathrm{c}}{ }_{\mathrm{H}_{2} \mathrm{O}}, \mathrm{P}_{\mathrm{Na}}$, and $\mathrm{U}_{\mathrm{Na}} \mathrm{V}$ all increased with time in the saline studies, it is conceivable

1 In the calculation of $\mathrm{T}^{\mathrm{c}}{ }_{\mathrm{Hz} 0}$ during saline diuresis, $\mathrm{P}_{\mathrm{osm}}$ is determined chiefly by $\mathrm{P}_{\mathrm{Na}}$. However, since this influence of $\mathrm{P}_{\mathrm{Na}}$ on $\mathrm{T}^{\mathrm{c}}{ }_{\mathrm{H}_{2} \mathrm{O}}$ would be to decrease $\mathrm{T}^{\mathrm{c}} \mathrm{H}_{2} \mathrm{O}$ [ $\mathrm{T}^{\mathrm{c}} \mathrm{H}_{2} \mathrm{O}$ $\left.=\mathrm{V}\left(\mathrm{U}_{\mathrm{osm}} / \mathrm{P}_{\mathrm{osm}}-1\right)\right]$, and since $\mathrm{T}^{\mathrm{c}} \mathrm{H}_{2 \mathrm{O}}$ rises with $\mathrm{P}_{\mathrm{Na}}$ despite this, it appears likely that they are functionally two independent variables. Hence a correlation coefficient is given for their relationship. 
TABLE III

Correlation coefficients in individual saline experiments*

\begin{tabular}{|c|c|c|c|c|c|c|}
\hline \multirow[b]{2}{*}{ Subject } & \multicolumn{2}{|c|}{$T^{c^{\circ}} \mathrm{H}_{2} \mathrm{O}$ vs. $P_{\mathrm{Nz}}$} & \multicolumn{2}{|c|}{$\begin{array}{c}\log U_{\mathrm{NaV}} \\
\text { vs. } \mathrm{P}_{\mathrm{Na}}\end{array}$} & \multicolumn{2}{|c|}{ 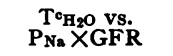 } \\
\hline & $\mathbf{r}$ & p & $\mathbf{r}$ & p & $\mathbf{r}$ & p \\
\hline LB & 0.963 & $<0.01$ & 0.752 & $<0.01$ & 0.619 & $<0.01$ \\
\hline $\mathrm{JC}$ & 0.963 & $<0.01$ & 0.606 & $<0.05$ & 0.516 & $>0.05$ \\
\hline RK & 0.949 & $<0.01$ & 0.701 & $<0.01$ & 0.723 & $<0.05$ \\
\hline FB & 0.982 & $<0.01$ & 0.724 & $<0.05$ & -0.780 & $<0.05$ \\
\hline PL & 0.926 & $<0.01$ & 0.891 & $<0.01$ & -0.186 & $>0.05$ \\
\hline $\mathrm{CS}$ & 0.979 & $<0.01$ & 0.958 & $<0.01$ & 0.295 & $>0.05$ \\
\hline MA & 0.980 & $<0.01$ & 0.988 & $<0.01$ & 0.279 & $>0.05$ \\
\hline
\end{tabular}

*Abbreviations as in Tables I and II. $\mathrm{P}_{\mathrm{Na}}=$ plasma sodium concentration.

that their relationships with each other were fortuitous. However, the very high degree of correlation of these variables in all saline experiments would suggest a physiologic interrelationship rather than a chance association. Furthermore, in the combined mannitol-hypertonic saline studies, during the early mannitol diuresis, $\mathrm{P}_{\mathrm{Na}}$ was decreasing and $\mathrm{T}^{\mathbf{c}} \mathrm{H}_{2} \mathrm{O}$ was relatively constant while $\mathrm{U}_{\mathrm{Na}} \mathrm{V}$ was increasing; only during the ensuing sa-

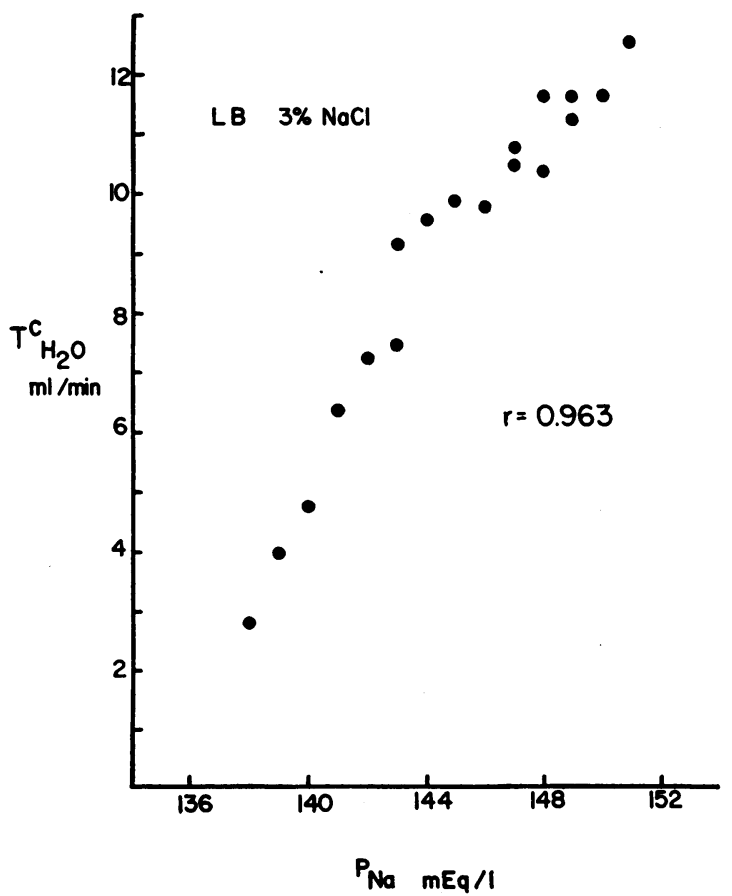

Fig. 5. RELATIONSHIP BETWEEN TUBULAR REABSORPTION OF SOLUTE-FREE WATER ( $T^{\mathrm{c}}{ }_{\mathrm{H}_{2} \mathrm{O}}$ ) AND PLASMA SODIUM CONCENTRATION $\left(P_{N_{2}}\right)$ DURING HYPERTONIC SALINE DIURESIS IN SUBJECT LB. Note the high linear correlation. line diuresis were these variables changing in the same direction. This indicates that the administration of hypertonic saline was responsible for the observed changes in these variables and their relationship to each other.

Glomerular filtration rate showed no consistent change in the mannitol experiments, but tended to rise during saline experiments. As seen in Table II, the mean GFR of the saline group at a $\mathrm{C}_{\text {osm }}$ of $17.9 \mathrm{ml}$ per minute per $1.73 \mathrm{~m}^{2}$ was higher than that of the mannitol group. Despite the tendency for the GFR to be higher during saline diuresis, these changes in GFR could not be closely related to the changes in $\mathrm{T}_{\mathrm{H}_{2} \mathrm{O}}$ in each experiment. In contrast to its high correlation with $\mathrm{P}_{\mathrm{Na}}, \mathrm{T}^{\mathbf{c}}{ }_{\mathrm{H}_{2} \mathrm{O}}$ was neither consistently nor closely correlated with changes in filtered load of sodium $\left(\mathrm{P}_{\mathrm{Na}} \times \mathrm{GFR}\right)$ (see Table III). This was despite the fact that the calculation of the filtered load employs the term $\mathrm{P}_{\mathrm{Na}}$ as a factor which, in itself, correlates highly with $\mathrm{T}^{\mathbf{c}}{ }_{\mathbf{H}_{2} \mathbf{O}}$. Furthermore, there were some experiments employing hypertonic saline in which GFR remained relatively constant despite a progressive rise in $\mathrm{T}_{\mathrm{H}_{2} \mathrm{O}}$. Table IV shows the detailed data from a single hypertonic saline experiment in which $\mathrm{T}^{\mathrm{c}} \mathrm{H}_{2} \mathrm{O}$ rose to a value of 11.1 $\mathrm{ml}$ per minute while GFR showed essentially no change. The protocol of a combined mannitolsaline study is presented in Table IC. In this study, the substitution of saline for the mannitol resulted in a progressive rise in $\mathrm{T}^{\mathbf{c}}{ }_{\mathrm{H}_{2} \mathrm{O}}$, after the latter had already levelled off with mannitol. Despite this effect of saline on $\mathrm{T}^{\mathrm{c}} \mathrm{H}_{2} \mathrm{O}$, there was no progressive rise in GFR, and the level of GFR during the saline diuresis was essentially the same as during the preceding mannitol diuresis.

\section{Discussion}

The data obtained during hypertonic mannitol diuresis are similar to other reported studies (3, $5,15,16)$. $\mathrm{T}_{\mathrm{H}_{2} \mathrm{O}}$ rises with increasing $\mathrm{C}_{\mathrm{osm}}$ to reach a maximal value, and simultaneously, urine osmolality falls curvilinearly to approach isotonicity. Zak, Brun, and Smith (3) and Page and Reem (4) have interpreted these observations as indicating that during antidiuresis, the concentrating mechanism operates by removing a constant quantity of solute-free water at high rates of $\mathrm{V}$. It has been suggested that this limit to $\mathrm{T}^{\mathrm{c}_{\mathrm{H}_{2} \mathrm{O}}}$ might 
reflect a limitation on the tubular transport of sodium in the ascending limb of the loop of Henle $(5,6)$, since this latter process probably is the source of solute necessary for generation of hypertonicity of the renal medulla and provides the osmotic gradient for reabsorption of water from the collecting duct (17). ${ }^{2}$

Our results with hypertonic saline diuresis are distinctly different from the mannitol studies, however, and do not fit into the above interpretation. At values of $C_{\text {osm }}$ above $12 \mathrm{ml}$ per minute per 1.73 $\mathrm{m}^{2}$, renal water reabsorption was greater with salt than with mannitol at a given $\mathrm{C}_{\text {osm }}$. In addition, no evidence for a maximal limit to $\mathrm{T}^{\mathrm{c}} \mathrm{H}_{2} \mathrm{O}$ was observed even at values of $\mathrm{C}_{\text {osm }}$ exceeding $27 \mathrm{ml}$ per minute per $1.73 \mathrm{~m}^{2}$. Porush, Goldstein, Eisner, and Levitt infused $2.5 \%$ sodium chloride and $10 \%$ mannitol into normal hydropenic humans (15). They also observed that $\mathrm{T}^{\mathrm{c}} \mathrm{H}_{2} \mathrm{O}$ is higher during saline diuresis compared to mannitol diuresis at comparable rates of $\mathrm{C}_{\text {osm }}$. The configuration of their salt curve, however, was similar to the mannitol curve, manifesting an upper limit. A critical appraisal of this apparent discrepancy between their data and ours cannot be made because their data were plotted in a composite form rather than as individual experiments.

Renal tissue slice analyses in hydropenic dogs undergoing hypertonic mannitol or saline diuresis have shown that total solute concentration of tissue water in the papillary tip is approximately the same as the $U_{\text {osm }}(19,20)$. Moreover, the con-

2 During this discussion, $\mathrm{T}^{\mathrm{c}} \mathrm{H}_{2} \mathrm{O}$ will be taken as a reflection of the solute-free water passively reabsorbed from the collecting duct during the concentrating operation. We realize that there are possible errors in this assumption. For example, failure of osmotic equilibration with body fluids in the late distal tubule would tend to invalidate this assumption. However, during osmotic diuresis in the rat, osmotic equilibration does occur in the late distal tubule (7). Moreover, in contrast to the dog, normal man and the rat do not excrete a dilute urine at moderately high rates of solute excretion. Another factor to be considered is the reabsorption of significant quantities of solute from the collecting duct. Although it has been shown that solutes are reabsorbed from the collecting duct (18), a tubular maximum for sodium reabsorption in the distal nephron appears to be present $(8,9)$, so that at high rates of solute excretion, the ratio of sodium reabsorbed distally to sodium excreted becomes progressively smaller; thus, calculated $T^{c}{ }_{\mathrm{H}_{2} \mathrm{O}}$ is probably a good index of free water reabsorption. centrations of urea (which is low) and of NUS in papillary tissue are comparable to their concentrations in urine. Hence, if we assume osmotic equilibration between final urine and the renal medulla to have occurred in the present studies, higher concentrations of solute( sodium chloride) were achieved in the medullary interstitium with salt diuresis as compared to mannitol diuresis. This indicates a higher rate of medullary solute accumulation with saline in order to maintain hypertonicity in the face of increasing water reabsorption. These differences in solute accumulation between salt and mannitol diuresis might be due to differences in the effects of the loading solutes on the medullary circulation. Either an increase in medullary blood flow specifically due to mannitol, or a decrease in medullary blood flow specifically due to hypertonic salt, or both, could result in the differences in the medullary solute concentrations. There is, however, no evidence to suggest that these two solutes would have different or opposite effects on medullary blood flow. Regardless of changes in blood flow, it seems necessary to assume a higher rate of tubular transport of sodium from the ascending limb of Henle's loop into the medulla during salt diuresis compared to mannitol diuresis. Since $\mathrm{T}^{\mathrm{c}}{ }_{\mathrm{H}_{2} \mathrm{O}}$ increases progressively with increasing $\mathrm{C}_{\text {osm }}$ during salt diuresis, no tubular maximum for sodium transport in the loop of Henle appears to exist.

The above interpretation is compatible with the results of micropuncture studies in rats undergoing hypertonic saline diuresis during hydropenia. Independently, Giebisch, Klose, and Windhager (8) and Lassiter, Mylle, and Gottschalk (9) demonstrated that, despite increasing loads and concentrations of sodium entering the loop of Henle, early distal tubular hypotonicity is maintained at a level comparable to nondiuretic animals. These observations indicate increasing rates of reabsorption of sodium by the ascending limb and the absence of a tubular transfer maximum for sodium. In an earlier study in rats, Gottschalk and Mylle (7) obtained similar results and also presented data on $\mathrm{T}^{\mathrm{c}} \mathrm{H}_{2} \mathrm{O}$ during hypertonic salt diuresis. Similar to our observations with humans, no evidence for a maximal limit to $\mathrm{T}^{\mathrm{c}} \mathrm{H}_{2} \mathrm{O}$ was present.

Another species in which $\mathrm{T}^{\mathbf{c}}{ }_{\mathrm{H}_{2} \mathrm{O}}$ behaves qualitatively in a manner similar to man and rat is the 
seal, (Phoca vitulina). Page and his colleagues (21) studied saline diuresis during hydropenia in these animals, attaining rates of $\mathrm{C}_{\text {osm }}$ at which 16 to $18 \%$ of filtered solute was excreted. In almost all studies, $\mathrm{T}^{\mathbf{c}} \mathbf{H}_{2} \mathrm{O}$ continued to rise with increasing $\mathrm{V}$, and no maximum was observed.

In contrast to the behavior of $\mathrm{T}^{\mathrm{c}}{ }_{\mathrm{H}_{2} \mathrm{O}}$ during saline diuresis in man, rat, and seal is its behavior in dogs. Utilizing an experimental protocol in dogs similar to the one employed in the present study, we could find no consistent quantitative differences in $\mathrm{T}^{\mathrm{c}}{ }_{\mathrm{H}_{2} \mathrm{O}}$ or difference in the configuration of the $\mathrm{T}_{\mathrm{H}_{2} \mathrm{O}}$ curve between salt and mannitol diuresis $(19,20)$. Jaenike has made similar observations (22). In the dog, $\mathrm{T}^{\mathrm{c}}{ }_{\mathrm{H}_{2} \mathrm{O}}$ often tends to fall precipitously at moderate rates of $\mathrm{C}_{\mathrm{osm}}$, and occasionally in both types of diuresis, a hypotonic urine is excreted in the presence of maximal antidiuretic hormone $(20,23)$. This latter phenomenon probably indicates that at moderately high rates of $\mathrm{V}$, osmotic equilibrium fails to occur at the end of the distal tubule in dogs. Therefore, calculated $\mathrm{T}^{\mathbf{c}} \mathrm{H}_{2} \mathrm{O}$ is not a good index of water reabsorption from the collecting duct.

Maude and Wesson (24), utilizing a different type of experimental approach in dogs, arrived at conclusions similar to ours concerning sodium transport in the loop of Henle. In conscious dogs, during long-term steady-state osmotic diuresis, with either hypertonic saline or urea, they found that $\mathrm{T}^{\mathrm{c}}{ }_{\mathrm{H}_{2} \mathrm{O}}$ can be augmented by substituting one loading solute for the other. They found no in-

TABLE IV

Protocol of a hypertonic saline experiment (subject CS) in which $\mathrm{T}_{\mathrm{H}_{2} \mathrm{O}}$ increased without concomitant changes in GFR*

\begin{tabular}{|c|c|c|c|c|c|c|}
\hline Time & V & Uosm & $\mathrm{C}_{\text {osm }}$ & $\mathrm{T}^{\mathrm{e}} \mathrm{H}_{2} \mathrm{O}$ & $\mathrm{U}_{\mathrm{NaV}}$ & GFR \\
\hline $\min$ & $\mathrm{ml} / \mathrm{min}$ & $\mathrm{mOsm} / \mathrm{kg}$ & $\mathrm{ml} / \mathrm{min}$ & $m l / m i n$ & $\mu E q / \min$ & $m l / \min$ \\
\hline $0-27$ & 1.1 & 1,017 & 3.7 & 2.6 & 266 & 114 \\
\hline 27 & \multicolumn{6}{|c|}{ Start infusion of $3 \% \mathrm{NaCl}$ at $12 \mathrm{ml} / \mathrm{min}$} \\
\hline $27-52$ & 1.0 & 954 & 3.3 & 2.3 & 279 & 107 \\
\hline $52-72$ & 1.9 & 932 & 6.0 & 4.1 & 565 & 134 \\
\hline $72-92$ & 2.7 & 801 & 7.3 & 4.6 & 748 & 131 \\
\hline $92-112$ & 3.9 & 743 & 9.9 & 6.0 & 1,110 & 129 \\
\hline $112-132$ & 5.3 & 650 & 11.6 & 6.3 & 1,230 & 118 \\
\hline $132-152$ & 10.3 & 575 & 19.7 & 9.4 & 2,560 & 141 \\
\hline $152-172$ & 13.7 & 516 & 23.3 & 9.6 & 3,230 & 136 \\
\hline $172-192$ & 16.0 & 495 & 25.8 & 9.8 & 3,700 & 136 \\
\hline $192-222$ & 16.7 & 495 & 26.6 & 9.9 & 3,830 & 134 \\
\hline $222-230$ & 20.5 & 480 & 31.6 & 11.1 & 4,460 & 142 \\
\hline
\end{tabular}

* Abbreviations as in Tables I and II. trinsic maximum for $\mathrm{T}^{\mathrm{c}_{\mathrm{H}_{2} \mathrm{O}}}$ and therefore no evidence for a tubular transfer maximum for sodium in the loop of Henle.

The apparent limit for $\mathrm{T}^{\mathrm{c}}{ }_{\mathrm{H}_{2} \mathrm{O}}$ with mannitol and not with saline diuresis may be explained by considering current knowledge on the mechanisms of these two types of diuresis. In 1948 Wesson and Anslow (25), employing mannitol diuresis in dogs, developed the concept of a critical gradient for sodium between proximal tubular urine and plasma to explain the natriuresis. According to this idea, the presence of nonreabsorbable excretory products in the tubule limits the reabsorption of water and thereby lowers the intratubular sodium concentration. When, at some point in the tubule, the tubular lumen to plasma sodium gradient exceeds a critical value, tubular reabsorption of sodium is retarded. Utilizing the stopped-flow microperfusion technique in single proximal tubules of the Necturus kidney, Windhager and associates have directly demonstrated a critical concentration gradient for sodium which, when exceeded, results in a reversal of net sodium movement (26). The role of this limiting gradient during mannitol diuresis was more strongly suggested by micropuncture studies in the rat by Windhager and Giebisch (10). As proximal tubular sodium concentration declined, tubular reabsorption of sodium and water decreased so that $10 \%$ less sodium was reabsorbed during mannitol diuresis than in nondiuresis.

Micropuncture studies in rats undergoing hypertonic saline diuresis revealed a different mechanism for the natriuresis $(8,9)$. As proximal tubular load and concentration of sodium increased, fractional reabsorption of sodium remained unchanged in the proximal tubule and loop of Henle. No proximal tubular transfer maximum was demonstrable. With increasing diuresis, more absolute quantities of sodium were reabsorbed and more escaped reabsorption compared to the nondiuretic state. In contrast, a tubular maximum for sodium was present in the distal nephron. Although, from these studies, reabsorption of sodium in the proximal tubule and loop of Henle was probably related to the rate of sodium delivery, it is apparent that tubular sodium concentration also plays a critical role in sodium reabsorption within the proximal nephron. If active tubular transport of sodium is analogous to transport in the toad blad- 
der epithelium, then the entrance of sodium into cells by a complex interaction with the surface appears to be an initial rate-limiting step. Below saturation levels, a rise in sodium concentration is associated with an increase in transepithelial transport (27).

From the above considerations, if tubular transport of sodium in the loop of Henle behaves in a manner qualitatively similar to the proximal tubule, then an explanation of the differences between salt and mannitol diuresis in the present study is possible. Mannitol, by lowering the sodium concentration in tubular fluid entering the loop, imposes a limitation on sodium transfer from the ascending limb into the renal medulla. This latter mechanism may be responsible for the observed limitation to $\mathrm{T}^{\mathrm{c}}{ }_{\mathrm{H}_{2} \mathrm{O}}$. On the other hand, during hypertonic saline diuresis, as both the rate of delivery of sodium to the loop and sodium concentration of fluid entering the loop are increased, progressively more sodium is transported into the medulla. This is reflected in the increasing $\mathrm{T}^{\mathrm{c}}{ }_{\mathrm{H}_{2} \mathrm{O}}$ without evidence of a maximum.

The concept of a decreased tubular sodium concentration retarding sodium reabsorption in the loop of Henle has been employed by Maude and Wesson (24), and Goodman, Cohen, Levitt, and Kahn (28) to explain their data on osmotic diuresis in dogs. It can also explain the observations of Stein and co-workers (16). These investigators found a lower maximal limit to $\mathrm{T}^{\mathbf{c}} \mathrm{H}_{2} \mathrm{O}$ during a mannitol diuresis in salt-depleted human subjects than in normal subjects. Aminophylline corrected the defect in $\mathrm{T}^{\mathbf{c}}{ }_{\mathrm{H}_{2} \mathrm{O}}$ when administered at low rates of $\mathrm{C}_{\text {osm }}$ but caused no improvement in $\mathrm{T}^{\mathrm{c}}{ }_{\mathrm{H}_{2} \mathrm{O}}$ at a high $\mathrm{C}_{\mathrm{osm}}$. Since aminophylline increases GFR, the delivery of more sodium to the loop before severe hyponatremia and hyponatriuria develop would be expected to increase sodium transport in the loop. At high values of $\mathrm{C}_{\mathrm{osm}}$, aminophylline would increase the sodium load to the loop of Henle, but the lowered concentration of sodium in tubular fluid would be inhibitory to tubular transport.

The correlation between $\mathrm{T}^{\mathrm{c}}{ }_{\mathrm{H}_{2} \mathrm{O}}$ and $\mathrm{P}_{\mathrm{Na}}$ in our saline studies may be pertinent. Since, with saline loading, the proximal tubular urine to plasma sodium ratio remains unity $(8,9)$, the $\mathrm{P}_{\mathrm{Na}}$ reflects the concentration of sodium entering the loop. $\mathrm{T}^{\mathrm{c}} \mathrm{H}_{2} \mathrm{O}$ is an index of sodium reabsorption in the loop. Our data are therefore compatible with the presence of a tubular transport system for sodium in the loop operating below saturation in which sodium reabsorption is proportional to the tubular concentration of sodium. Kamm and Levinsky (29), studying hypertonic saline diuresis in dogs, noted a relationship between over-all renal tubular reabsorption of sodium and $\mathrm{P}_{\mathrm{Na}}$ that is independent of changes in GFR.

Since GFR tended to be higher with saline than with mannitol diuresis, it is possible that the level of GFR was a factor influencing the quantitative differences in $\mathrm{T}^{\mathrm{c}} \mathrm{H}_{2} \mathrm{O}$ between the two types of diuresis. Goldsmith and colleagues (30) showed that $\mathrm{T}^{\mathrm{c}}{ }_{\mathrm{H}_{2} \mathrm{O}}$ during mannitol diuresis in dogs correlated closely with GFR. In our studies, however, $\mathrm{T}^{\mathrm{c}} \mathrm{H}_{2} \mathrm{O}$ during saline diuresis did not correlate well with GFR. In some experiments, a progressive rise in $\mathrm{T}^{\mathrm{c}} \mathrm{H}_{2} \mathrm{O}$ was noted without increases in GFR. Hence it is difficult to implicate GFR as the most important factor determining the qualitative or quantitative differences in $\mathrm{T}^{\mathrm{c}} \mathrm{H}_{2} \mathrm{O}$ observed in these studies.

\section{Summary}

The acute effects of infusions of $10 \%$ mannitol, $3 \%$ sodium chloride, and a combination of these were studied in hydropenic human subjects. During mannitol diuresis, tubular reabsorption of solute-free water $\left(\mathrm{T}_{\mathrm{H}_{2} \mathrm{O}}\right)_{\text {) }}$ rose to achieve an upper limit or maximum when solute clearance $\left(\mathrm{C}_{\text {osm }}\right)$ exceeded $12 \mathrm{ml}$ per minute per $1.73 \mathrm{~m}^{2}$. In contrast to mannitol diuresis, hypertonic saline diuresis was characterized by a progressive rise in $\mathrm{T}^{\mathrm{c}} \mathrm{H}_{2} \mathrm{O}$ with no evidence of a maximum at rates of $\mathrm{C}_{\text {osm }}$ exceeding $27 \mathrm{ml}$ per minute per $1.73 \mathrm{~m}^{2}$. $\mathrm{T}^{\mathbf{c}}{ }_{\mathrm{H}_{2} \mathrm{O}}$ rose linearly with $\log \mathrm{C}_{\mathrm{osm}}$, log sodium excretion, and with plasma sodium concentration.

We conclude that no evidence is present for an intrinsic tubular transfer maximum for sodium in the loop of Henle in man. Tubular sodium concentration appears to be a critical determinant of the rate of sodium transport. 'Decreasing the concentration of sodium with mannitol has an inhibitory effect on loop sodium transport and produces the apparent maximum to $\mathrm{T}^{\mathbf{c}} \mathbf{H}_{2} \mathbf{O}$. Raising the concentration with hypertonic salt increases the medullary transport and accumulation of sodium. 


\section{Acknowledgments}

The authors wish to thank Dr. J. Russell Elkinton for his support and encouragement during this study. We should like to acknowledge the technical assistance of Dolores Metz and Ellen Drace and to thank Lidia Kosolapovs, Leonid Kosolapovs, Katherine Wishnevski, and Edward Brown for the laboratory analyses.

\section{References}

1. Goldberg, M., D. K. McCurdy, and M. A. Ramirez. Absence of limitation to renal water reabsorption in hydropenic man (abstract). Clin. Res. 1964, 12, 252.

2. Rapoport, S., W. A. Brodsky, C. D. West, and B. Mackler. Urinary flow and excretion of solutes during osmotic diuresis in hydropenic man. Amer. J. Physiol. 1949, 156, 433.

3. Zak, G. A., C. Brun, and H. W. Smith. The mechanism of formation of osmotically concentrated urine during the antidiuretic state. J. clin. Invest. 1954, 33, 1064.

4. Page, L. B., and G. H. Reem. Urinary concentrating mechanism in the dog. Amer. J. Physiol. 1952, 171, 572.

5. Raisz, L. G., W. Y. W. Au, and R. L. Scheer. Studies on the renal concentrating mechanism. IV. Osmotic diuresis. J. clin. Invest. 1959, 38, 1725.

6. Berliner, R. W. Outline of renal physiology in Diseases of the Kidney, 1st ed., M. B. Strauss and L. G. Welt, Eds. Boston, Little, Brown, 1963, pp. 55-56.

7. Gottschalk, C. W., and M. Mylle. Micropuncture study of the mammalian urinary concentrating mechanism: evidence for the countercurrent hypothesis. Amer. J. Physiol. 1959, 196, 927.

8. Giebisch, G., R. M. Klose, and E. E. Windhager. Micropuncture study of hypertonic sodium chloride loading in the rat. Amer. J. Physiol. 1964, 206, 687.

9. Lassiter, W. E., M. Mylle, and C. W. Gottschalk. Net transtubular movement of water and urea in saline diuresis. Amer. J. Physiol. 1964, 206, 669.

10. Windhager, E. E., and G. Giebisch. Micropuncture study of renal tubular transfer of sodium chloride in the rat. Amer. J. Physiol. 1961, 200, 581.

11. Goldberg, M., D. K. McCurdy, E. L. Foltz, and L. W. Bluemle, Jr. Effects of ethacrynic acid (a new saluretic agent) on renal diluting and concentrating mechanisms: evidence for site of action in the loop of Henle. J. clin. Invest. 1964, 43, 201.

12. Conway, E. J. Microdiffusion Analysis and Volumetric Error, 4th ed. London, Crosly, Lockwood, 1957, pp. 162-174.

13. Snedecor, G. W. Statistical Methods, 5th Ed. Ames, The Iowa University Press, 1956.

14. Blythe, W. B., and L. G. Welt. Dissociation between filtered load of sodium and its rate of excretion in the urine. J. clin. Invest. 1963, 42, 1491.
15. Porush, J. G., M. H. Goldstein, G. M. Eisner, and M. F. Levitt. Effect of organomercurials on the renal concentrating operation in hydropenic man: comments on site of action. J. clin. Invest. 1961, 40, 1475.

16. Stein, R. M., B. H. Levitt, M. H. Goldstein, J. G. Porush, G. M. Eisner, and M. F. Levitt. The effects of salt restriction on the renal concentrating operation in normal, hydropenic man. J. clin. Invest. 1962, 41, 2101.

17. Gottschalk, C. W. Osmotic concentration and dilution of the urine. Amer. J. Med. 1964, 36, 670.

18. Klümper, J. D., K. J. Ullrich, and H. H. Hilger. Das Verhalten des Harnstoffs in den Sammelrohren der Säugetierniere. Pflügers Arch. ges. Physiol. 1958, 267, 238.

19. Goldberg, M., M. A. Ramirez, D. M. Wanicur, and J. R. Elkinton. Renal composition during hypertonic saline and mannitol diuresis in hydropenic dogs. Fed. Proc. 1964, 23, 362.

20. Goldberg, M., and M. A. Ramirez. Unpublished data.

21. Page, L. B., J. C. Scott-Baker, G. A. Zak, E. L. Becker, and C. F. Baxter. The effect of variation in filtration rate on the urinary concentrating mechanism in the seal, Phoca vitulina. J. cell. comp. Physiol. 1954, 43, 257.

22. Jaenike, J. R. Urea enhancement of water reabsorption in the renal medulla. Amer. J. Physiol. 1960, 199, 1205.

23. Earley, L. E., M. Kahn, and J. Orloff. The effects of infusions of chlorothiazide on urinary dilution and concentration in the dog. J. clin. Invest. 1961, 40, 857.

24. Maude, D. L., and L. G. Wesson, Jr. Renal water reabsorption during saline and urea osmotic diuresis in the dog. Amer. J. Physiol. 1963, 205, 477.

25. Wesson, L. G., Jr., and W. P. Anslow, Jr. Excretion of sodium and water during osmotic diuresis in the dog. Amer. J. Physiol. 1948, 153, 465.

26. Windhager, E. E., G. Whittembury, D. E. Oken, H. J. Schatzmann, and A. K. Solomon. Single proximal tubules of the Necturus kidney. III. Dependence of $\mathrm{H}_{2} \mathrm{O}$ movement on $\mathrm{NaCl}$ concentration. Amer. J. Physiol. 1959, 197, 313.

27. Frazier, H. S., E. F. Dempsey, and A. Leaf. Movement of sodium across the mucosal surface of the isolated toad bladder and its modification by vasopressin. J. gen. Physiol. 1962, 45, 529.

28. Goodman, B., J. A. Cohen, M. F. Levitt, and M. Kahn. Renal concentration in the normal dog: effect of an acute reduction of salt excretion. Amer. J. Physiol. 1964, 206, 1123.

29. Kamm, D. E., and N. G. Levinsky. Effect of plasma sodium elevation on renal sodium reabsorption. Amer. J. Physiol. 1964, 206, 1131.

30. Goldsmith, C., H. K. Beasley, P. J. Whalley, F. C. Rector, Jr., and D. W. Seldin. The effect of salt deprivation on the urinary concentrating mechanism in the dog. J. clin. Invest. 1961, 40, 2043. 